\title{
The Impact of President Election, Celebrity Endorsement, and Product Variation to Brand Image and Purchase Intention on Sang Pisang Business
}

\author{
Lidia Agustin ${ }^{1}$, Jony Oktavian Haryanto ${ }^{2}$, \\ Liza Agustina Maureen Nelloh ${ }^{3 *}$ \\ ${ }^{12}$ President University, North Cikarang, Bekasi West Java, 17530 , Indonesia \\ ${ }^{3}$ Sekolah Tinggi Manajemen IPMI, DKI Jakarta12750, Indonesia
}

\section{A B S T R A C T}

The situation of the 2019 presidential election was enough to take the attention of many parties in Indonesia because there were several conflicts. With the situation of the last presidential election, the researchers wants to examine the impact of it to the business of Sang Pisang that owned by Kaesang Pangarep who is the son of the Presidential Candidates in the 2019 presidential election, and also examine does Kaesang Pangarep's popularity as a celebrity or influencers, the variety of products and brand image have influenced the Sang Pisang Business. The findings of this study indicate that there is a direct effect of President Election, Celebrity Endorsement, Product Variation, and Brand Image towards Purchase Intention, there is direct effect of the Celebrity Endorsement towards Brand Image and also there is indirect effect of Celebrity Endorsement towards Purchase Intention mediated by Brand Image of Sang Pisang in Jabodetabek, and all of the effect is significant.

\section{A R T I C L E I N F O}

Article History:

Received : 26-07-2021

Revised : 23-08-2021

Accepted : 24-10-2021

Published : 31-10-2021

Keywords:

President Election

Celebrity Endorsement

Product Variation

Brand Image

Purchase Intention

JEL: M10, M21, M31

*Corresponding Author E-mail:

liza.nelloh@ipmi.ac.id

Copyright (C) 2021 Authors. This is an open access article distributed under the Creative Commons Attribution License (CC-BY-SA 4.0) which permits use, distribution and reproduction in any medium, provided the original work is properly cited \& ShareAlike terms followed.

\section{INTRODUCTION}

Indonesia is one of the country that uses a democratic system because Indonesia upholds human dignity like the meaning contained in the word democracy itself. Democracy is a government that involves all citizens whether 
rich or poor, educated or uneducated, women or men, and of all classes of social status because all citizens have equality in the ownership of the privilege of making decisions for the nation, because the Indonesia is our nation belongs together. Because of democracy, citizens are allowed to participate in something important in this country such as conducting elections for the local Citizens' Board, the Governor, and also the President. Presidential elections in Indonesia are held every 5 years.

In 2019 Indonesia has elected the President and Vice President for the 2019-2024 period. Where all Indonesian people participate in electing the President and Vice President. This election was won by Joko Widodo and his vice Ma'ruf Amin, where previously President Jokowidodo had served as President in the first period, then he won the next election which is in 2019. Mr. Jokowidodo and his wife Mrs. Irma have three children, two of them are male and one is female. They are Gibran Rakabuming Raka, Kahiyang Ayu, and Kaesang Pangarep. Becoming an entrepreneur is the career choice of Kaesang Pangarep, the youngest son of President Joko Widodo. Kaesang Pangarep is the last child of Mr. Joko Widodo who was born in the city of Surakarta on December 25, 1994, Kaesang is a film actor, YouTuber, and food entrepreneur. One of his businesses is a banana culinary business called Sang Pisang. Kaesang Pangarep is a young man who is very serious about running his business, especially in the culinary business. Sang Pisang banana nugget business is growing fast, and has opened many store in several regions in Indonesia, and also in other country. Based on the previous study, it reveals that celebrity endorsers have significant effects in several countries like Malaysia, Australia, and Indonesia (Lesmana et al, 2021). Hence, the study would recommend to use celebrity endorser for luxury products but not for entrepreneurs in Indonesia. Therefore, this study will confirm the importance of celebrity endorsers for entrepreneurs in Indonesia.

\section{LITERATURE REVIEW}

\section{Presidential Election}

(Adisa, 2010) argues that the government system is very good and ideal when the highest sovereignty and controlling power in decisions relating to the state are under the control of all citizens so that every citizen also has the right in state decisions so that citizens participate in government roles. (Adesina, 2016) argues that in a government that adopts a democratic system have the perfect criterion when they have effective participation from the community.

According to (Agu, Okeke \& Idike, 2013) the political system that democratic is seen from the decision making process where the election candidates are chosen by the community through fair, honest and periodic elections where election candidates can compete honestly through their respective strategies to get the voting from the people who have fulfilled the requirements for voting. According to (Hung, 2011) the presidential election is the most powerful political event because the President has an important position for a country that has the authority to make policies for the country. (Chauvet \& Collier, 2008) consider that elections can influence economic policies before and after the election period.

According to (Somoye, 2016) there is a power in business that is owned by someone who respected and trusted so that it can influence people in doing something. (Kanter, 1979) argues that the effectiveness of one's power can come from the support obtained to carry out the task. (Cliffs, 1984) behavior in society is influenced by someone who has the power to influence them. Government, especially presidential elections, can affect the results obtained by a community because of the influence of a figure who is an important person or famous either directly or indirect (Lobo et al., 2016). Presidential elections can affect a community's progress when it comes to their presidential candidates because the presidency is the most important election for a country (Lobo et al., 2016). The results obtained by a community due to the influence of a figure who is an important or well-known 
person, both directly and indirectly is the response of the masses to the institution because voters will support those who have the presidential candidate they choose, because they like individual characteristics or policies from these presidential candidates (Randall L. Calvert and John A. Ferejohn, 1983; Shugart, 1995). High attention for presidential candidates will attract the attention of voters on a community associated with the presidential candidate (West \& Spoon, 2017).

\section{Celebrity Endorsement}

Personal characteristics of a celebrity or how a celebrity presents themselves uniquely can attract their fans so that celebrities make their identities and followers interact in accordance with the celebrity's identity (Li, 2018; H. J. Park \& Lin, 2020). Celebrity is very influential in supporting product sales, influencing advertising effectiveness, and purchase intentions (Gong \& $\mathrm{Li}$, 2017). Celebrities can produce positive impact for customers towards brand and purchase intention (Chung \& Cho, 2017), so many companies have a strategy to advertise their products using celebrities in order to get consumers' intentions.

Celebrities have the expertise that makes products more desirable or enhances perceptions of quality, and the image of celebrity endorsers is transferred to the product so that those who use the product are associated with the celebrity's image (Clark \& Horstman, 2003). Celebrity support can improve consumers' recall of products and consumers can increase the value of the product after receiving support from celebrities. (Zafer, 2010) defines a celebrity to be regarded as a communicator who is considered a legitimate source of statements by consumers.

Endorsers can influence consumer purchase intentions if consumers get a positive vibe and the endorsers have the ability to direct consumers to buy products (Davis et al., 2017), because celebrities have advantages in their ability to trigger consumer purchase intentions (Samad et al., 2019). Through celebrities, consumers can easily get advertising information and easily have an interest in advertising because of the celebrity's involvement which can lead to consumer purchase intentions (Hassana \& Jamil, 2014). The popularity of a celebrity can rise depending on the level of their performance and how they maintain it (Koshy \& Manohar, 2017).

Celebrities are able to produce actual buying behavior and have a good impact on the company's economy (Kumar \& Venkata Ramana, 2019). Celebrity can influence consumer buying behavior and celebrity support will be more effective and maximum when the celebrity image matches with the image of the product they support (Chung \& Cho, 2017). The use of advertisements by celebrities for companies has been widely used and has become a trend to build a brand image and purchase intention (Koshy \& Manohar, 2017).

\section{Product Variations}

Product variations is a concept when there are a number or various products that are marketed from the same type but have differences and uniqueness in the character or quality of the product (Landahl \& Johannesson, 2018). In the industrial world, variations in products can meet the various needs and tastes of different customers, the number of variants will affect the industry because with the product variation will meet the specific needs and tastes of customers, product variation created to meet the various preferences and specific needs of customers that are different for each individual. (Landahl \& Johannesson, 2018). According to (Sethi et al., 2017), variations in products can affect purchasing intention on consumers. (Mehrjoo \& Pasek, 2014) said that changes in product variations not only benefit consumers but will also affect company revenues, a wide variety of products will benefit consumers and lead to increased sales that profitable for the company. Product variations allow consumers to make various selections that can bring change and bring new things to keep consumers away from boredom, so consumers can explore the variations of these products (Sethi et al., 2017). 
The company or businessman increases an important element of the product that is variety to attract the attention of more consumers so the customer will satisfied because customer preferences for the product can be met and customers can buy products that suit their needs or desires. The variety of products displayed will satisfy more customers, thereby increasing purchase intention. Consumers have demand for a variety of products because each individual has different preferences for each product variant. To meet the different demands of customers, the company tries to offer a variety of different products, companies have product variations to produce purchase intentions from consumers who may have differences in the assessment of quality, tastes, or budget constraint preference, and companies are good and can be superior compared with their competitors if they can meet the needs and desires of consumers that can change rapidly. Companies with a strategy to increase consumer purchase intention by introducing more variation products in competing with competitors in order to compete for consumer attention(T. Park et al., 2005). Companies also use the product variation strategy to keep existing customers to continue to have purchase intentions for their products (Rajagopalan \& Swaminathan, 2001).

\section{Brand Image}

Brand is a characteristic with a combination of terms, designs, names, symbols or other features that differentiate one company's products with another so that it can identify the company's goods or services (Foster, 2017). The main goal of those who offer brands in various markets is to create strong brands that will be liked, and chosen by customers in various ways (Keller, 2016). Brands are seen as a very important asset for companies to identify offers and as a good communicator tool, strong brands are the expectations of the company, to increase the strength of the company's brand and obtain good judgment and have brand support from various parties will provide market power (Davcik et al., 2015).
Marketing activities carried out by companies produce brand image (Chien-hsiung, 2011; Dunuwille \& Pathmini, 2016). Brand image is formed from the public's view of the brand (Black \& Veloutsou, 2017). We can make the public opinion through planned actions of the quality of branded goods that produce a good image (Kalieva, 2015). Brand image makes decisions about strategic marketing better, especially in terms of making certain target market segments and in terms of product positioning (Lee et al., 2014).

In order to have a good brand image, companies are expected to be able to develop a brand with a strong and profitable reputation, which is expected from the company and their stakeholder network (Keller, 2016). Brand image is an illustration of the way consumers think about the brand of a product and the feelings that the brand brings to their minds when they think of the brand (Keller, 2001). If the brand image is strong, the brand image has a good effect on consumers' perceptions of the brand, which will make consumers more likely to choose the brand than its competitors, and this shows that a brand with a good image will be more competitive (Mohammadzadeh, 2015). According to (Mohammadzadeh, 2015), a strong brand image can make better pricing strategies, maximum promotional efforts, and the effectiveness of the company's brand distribution. Likewise, according to (Malik et al., 2012) brand image has a very influential effect on the company's activities in promoting it's brand.

Brand image is a view that is strong in the minds of consumers towards a brand, which is a reflection of consumers' memories about brand associations (Kessuvan et al., 2015). (Haque et al., 2015) have noted that brand image is what will come to mind of people when they see a brand. In measuring how much influence the brand image has on customer loyalty to a brand, it has been stated that the brand image consists of the product image itself, the company image, and the competing brand image so that in order to increase customer loyalty to a brand the company 
need to improve the product image and company image too (Haque et al., 2015).

Brand image is unique in the minds of customers about the implicit promises that exist in the brand and what the brand offers to customers (Foster, 2017). Brand image is the thoughts and trust held by customers in consumers' memories (Chien-hsiung, 2011). (Foster, 2017) views the brand image as a process by which a person can select, organize and interpret the information entered to make a meaningful description.

Brand image can be interpreted as a thought obtained by consumers or the views formed on consumers of a brand, brand image is a brand association that is formed in the minds of consumers of the brand so that consumers can know whether a brand can be superior or less superior compared to other brands and good brand image will make purchases by consumers (Foster, 2017).

According to (Alnazer, 2013) brand image is a kind character, nature, strengths, or weaknesses in the minds of consumers in considering a particular brand. The right brand image of the product will affect consumer evaluations of the brand (Widyastutir \& Said, 2017). Brand image is a very important concept in marketing for companies (Davcik et al., 2015). Brand image is a very influential factor that not only influences consumers' perceptions of good and consumer attitudes towards products, but brand image is also very influential in purchasing products for consumers to measure consumer purchase intentions as well (Haque et al., 2015).

\section{Purchase Intention}

Purchase Intention is a tendency or desire that arises from consumers to buy certain products or services (Yoo et al., 2000). Purchase intention is a plan that exists in a person to buy a product or service (Abumalloh, 2018). Purchase Intention can arise in consumers if consumers plan to buy a product or service and have money that can afford products or services that are budgeted to buy. In addition, purchase intention can also arise if consumers can consider buying the product so that they have a tendency to buy products or the service (Diallo, 2012).

Purchase intention is defined as the driving force for buying products and services for consumers (Haque et al., 2015). The most common step taken by marketers to understand what consumers want is to learn their intentions (Ghalandari \& Norouzi, 2012). (Kim \& Thorndike Pysarchik, 2000) have shown a strong correlation between consumer desires and consumer intentions. Purchase intention is an important thing that can move consumers to buy the product or service offered because intention is motivation for consumers that greatly influences their decision in choosing a product so that the products we offer will actually be purchased by individuals and it all depends on strength their intention, if the intention is higher then the possibility to do something, is also high (Haque et al., 2015).

Purchase intentions is the existence of consumers' tendencies in actual purchases with clear objectives, and buying intention is the possibility of buying a brand (Vahdati \& Nejad, 2016). There are several factors that can influence consumer intentions when choosing products and the final decision chosen by consumers depends on consumer intentions with external factors (Keller, 2001). Information about the brand of a product can be used to influence purchase intention, thus, in an orientation environment towards the members of the consumer it has a very positive effect which has an effect on influencing other members to buy certain brands used by members of the group (Younus et al., 2015).

Purchase Intention arises when consumers know about the product itself, attractive variations are also important because consumers are interested in what they see, and interesting variations will build goodwill and also show good product quality (Younus et al., 2015). The higher product value for customers will produce higher purchase intentions and consumers can look to a product offered and make a decision (Younus et al., 2015). 


\section{Brand Image to Purchase Intention}

Brand image has an influence on purchase intentions, if a product has a positive image, the consumer's intention to buy the product will be high, from this it can be concluded that brand image is a consideration by consumers in making purchasing decisions because brand image increases purchase intentions (Wang \& Tsai, 2014). Brand image can positively and significantly influence purchase intentions (Made et al., 2018). (Mendrofa, 2012) conducted a research with results that showed that purchase intention was positively influenced by brand image. According to (Iswara \& Jatra, 2017) brand image influences purchase intention positively and significantly. By having a good brand image, the company can create a higher consumer purchase intention because the better the brand image, the higher the tendency of consumers to buy the product and the products with a good brand image will be more trusted by consumers and consumers will assume that products with a good brand image are safer to buy (Made et al., 2018).

\section{Hypotheses Development}

Based on the theory above, the hypotheses and literature framework formed is as follow:

According to the theory (Lobo et al., 2016), government, especially presidential elections, can affect the results obtained by a community because of the influence of a figure who is an important person or famous either directly or indirect, this is the hypothesis regarding the research topic about the impact of president election to purchase intention:

H1 :Presidential election positively affect the purchase intention.

According to the previous theory that endorsers can influence consumer purchase intentions if consumers get a positive vibe and the endorsers have the ability to direct consumers to buy products (Davis et al., 2017), because celebrities have advantages in their ability to trigger consumer purchase intentions (Samad et al., 2019), this is the hypothesis regarding the research topic about the impact of celebrity endorsement to purchase intention:
H2 :Celebrity endorsement positively affect the purchase intention.

According to the theory the use of advertisements by celebrities for companies has been widely used and has become a trend to do this to build the brand image and product marketing (Parasher \& Ghosal, 2005), this is the hypothesis regarding the research topic about the impact of celebrity endorsement to brand image:

H3 :Celebrity endorsement positively affect the brand image.

According to the theory (Sethi et al., 2017), variations in products can affect profitability and purchasing intention on consumers, this is the hypothesis regarding the research topic about the impact of variety of product to purchase intention:

H4 :Product Variations positively affect the purchase intention.

According to (Iswara \& Jatra, 2017), brand image influences purchase intention positively and significantly, this is the hypothesis regarding the research topic about the impact of brand image on purchase intention:

H5 :Brand image positively affect the purchase intention.

\section{Theoretical Framework}

There are three dominant factors that contained independent factors and two dependent factors in this research, the independent factors are President Election as X1, Celebrity Endorsement as $\mathrm{X} 2$, Products Variation as $\mathrm{X} 3$, the mediator variable is Brand Image as $\mathrm{Y}$, and the dependent variable is Purchase Intention as $\mathrm{Z}$.

\section{RESEARCH METHOD}

There are two methods that can be used when conducting scientific research, namely quantitative research and qualitative research (Sugiyono, 2017). The purpose of using quantitative methods is to determine whether the theoretical generalizations of the theory are true or not in some cases. Population is a generalization of the region of all things related cases that have specific 


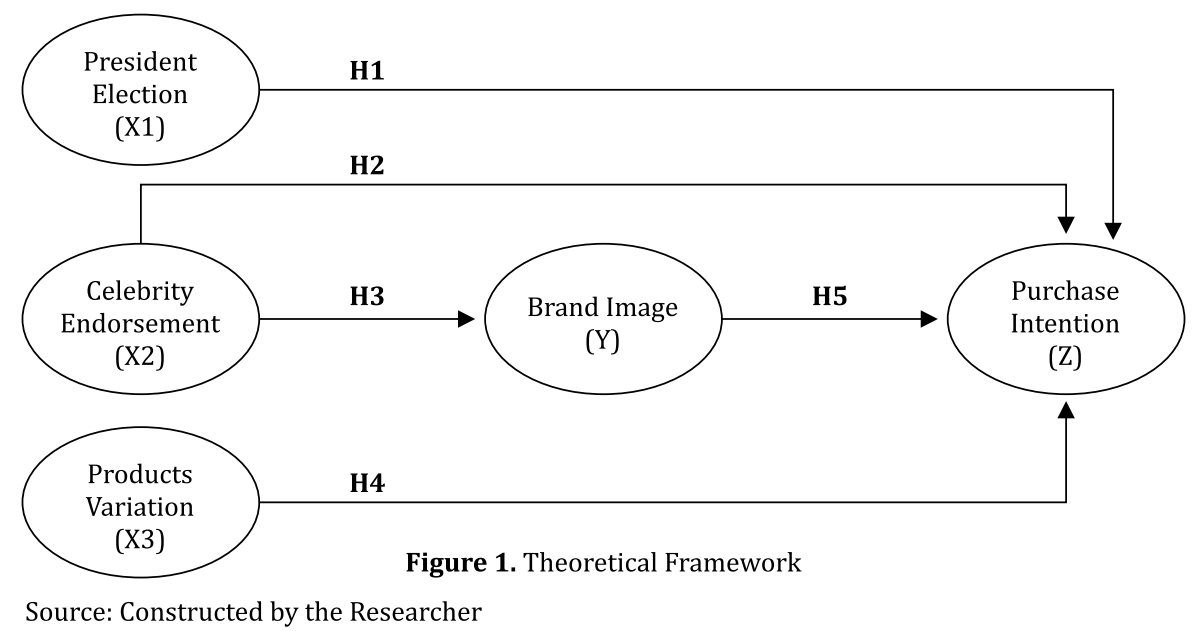

qualities and characteristics which are included as the subject of research that cannot always be explained in the right amount (Etikan, 2016). This research population group is Jabodetabek area who have heard about the Sang Pisang products. Jabodetabek is the name given from the initials of several city names consisting of the city of Jakarta and surrounding cities those are Bogor, Depok, Tangerang, and Bekasi. According to (Etikan, 2016), sample is part of the population that reflects characteristics that are in accordance with research in the population. Non-probability sampling that researchers use in collecting the sample is purposive sampling that usually called with judgmental, selective or subjective sampling technique (Sekaran \& Bougie, 2016). Purposive sampling is a way to take samples of research when researchers have certain considerations in determining population members who can participate in this research (Sugiyono, 2013). The criteria that researchers use as research samples are men or women who have heard about Sang Pisang products, and living or domiciled in JABODETABEK area (Jakarta, Bogor, Depok, Tangerang, and Bekasi). The minimum number of samples of this research would be 125 respondents. However, there were 200 respondents that fill questionnaire that meet the researcher criteria.

The researcher uses a Likert Scale so it gives freedom for the sample to answer the questions in the questionnaire. Questionnaires were distributed using closed questions. Likert Scale contained 5 points which is strongly disagree (score 1), disagree (score 2), neutral (score 3), agree (score 4) and strongly agree (score 5).

Researchers used 30 respondents to conduct a Pre-test, the validity of the questions in the questionnaire the researcher measures by looking at the level of accuracy between the real data that occurs in the object of research with information that can be accounted for by the researcher, the number of correlation coefficient is 0.3610 (Sugiyono, 2017). Reliability test is a method conducted by researchers to check the accuracy of scores or repeatabiliy from the pretest questionnaire that researchers distribute (Thompson, 2013), the higher the alpha value is more better and the reliability test score shall not be less than 0.6 (Ghozali, 2011).

The results of hypotheses in the research model can be done through PLS by analyzing the results of the bootstrap (Garson, 2016), in this study, researcher use SmartPLS 3 software.

\section{RESULT AND DISCUSSION}

Pretest respondent is Jabodetabek residents (Jakarta, Bandung, Bogor, Tangerang and Bekasi) who have heard about Sang Pisang products and live in Jabodetabek area. Researchers use questionnaires as a tool to collect pretest data from research samples. In this pretest there were 30 respondents who had filled out the questionnaire. This research question will be considered as valid if the value of correlation is 
greater than 0.3610 , this number was obtained from $r$ table distribution for $\mathrm{N}=30$ with 0.05 as a significant level.

Table 1. Validity Test Result

\begin{tabular}{|c|c|c|c|c|}
\hline Variables & & R Table & Total Correlation & Validity \\
\hline \multirow{5}{*}{$\begin{array}{l}\text { President } \\
\text { Election }\end{array}$} & Pe1 & 0.361 & 0.863 & Valid \\
\hline & PE2 & 0.361 & 0.774 & Valid \\
\hline & PE3 & 0.361 & 0.935 & Valid \\
\hline & PE4 & 0.361 & 0.831 & Valid \\
\hline & PE5 & 0.361 & 0.946 & Valid \\
\hline \multirow{5}{*}{$\begin{array}{l}\text { Celebrity } \\
\text { Endorsement }\end{array}$} & CE1 & 0.361 & 0.516 & Valid \\
\hline & CE2 & 0.361 & 0.825 & Valid \\
\hline & CE3 & 0.361 & 0.816 & Valid \\
\hline & CE4 & 0.361 & 0.861 & Valid \\
\hline & CE5 & 0.361 & 0.871 & Valid \\
\hline \multirow{5}{*}{$\begin{array}{l}\text { Product } \\
\text { Variation }\end{array}$} & PV1 & 0.361 & 0.790 & Valid \\
\hline & PV2 & 0.361 & 0.779 & Valid \\
\hline & PV3 & 0.361 & 0.928 & Valid \\
\hline & PV4 & 0.361 & 0.829 & Valid \\
\hline & PV5 & 0.361 & 0.797 & Valid \\
\hline \multirow{4}{*}{$\begin{array}{l}\text { Brand } \\
\text { Image }\end{array}$} & BI1 & 0.361 & 0.623 & Valid \\
\hline & $\mathrm{BI} 2$ & 0.361 & 0.772 & Valid \\
\hline & $\mathrm{BI} 3$ & 0.361 & 0.772 & Valid \\
\hline & $\mathrm{BI} 4$ & 0.361 & 0.771 & Valid \\
\hline
\end{tabular}

Source: Constructed in SPSS (2020)

The table explain that all of the question are valid because the value is more than 0.361 . So there are no statement will automatically deleted from the questionnaire.

The questionnaire is considered reliable if the Cronbach's alpha score is above 0.7 when analyzed using SPSS 16.0, table 2 below shows that Cronbach's alpha scores for all variables above 0.7, which means that the questionnaire is considered reliable. Therefore, this questionnaire can be used for research.

Table 2. Reliability Test Result

\begin{tabular}{lcc}
\hline Variable & Cronbach's Alpha & Reliability \\
\hline President Election & 0.821 & Reliable \\
\hline Celebrity Endorsement & 0.803 & Reliable \\
\hline Product Variation & 0.811 & Reliable \\
\hline Brand Image & 0.791 & Reliable \\
\hline Purchase Intention & 0.748 & Reliable \\
\hline
\end{tabular}

Source: Constructed in SPSS (2020)
In this study there were 238 respondents who had filled out the questionnaire but there were 200 respondents who passed the screening question. The following Table 3 is information on the demographic data of respondents collected by researchers on the questionnaire that was distributed:

To test the results of hypotheses in the research model, the researchers use SmartPLS 3 software to analyzing the results by using bootstrap. The following figure is the result of SEM model analysis using SmartPLS 3 software:

Table 4. Hypothesis Test of Direct Effect Result

\begin{tabular}{lccc}
\hline & T Statistics & P Values & Result \\
\hline $\begin{array}{lccc}\text { Celebrity Endorsement -> } \\
\text { Brand Image -> Purchase }\end{array}$ & 2.112 & 0.035 & Significant \\
Intentin & & & \\
\hline
\end{tabular}

Source: SmartPLS (2020)

Table 5. Hypothesis Test of Indirect Effect Result

\begin{tabular}{lcc}
\hline & T-Values & P-Values \\
\hline $\begin{array}{l}\text { President Election to } \\
\text { Purchase Intention }\end{array}$ & 2.260 & 0.024 \\
\hline $\begin{array}{l}\text { Celebrity Endorsement to } \\
\text { Purchase intention }\end{array}$ & 2.643 & 0.008 \\
\hline $\begin{array}{l}\text { Celebrity Endorsement } \\
\text { to Brand Image }\end{array}$ & 7.153 & 0.000 \\
\hline $\begin{array}{l}\text { Product Variation to } \\
\text { Purchase Intention }\end{array}$ & 9.685 & 0.000 \\
\hline $\begin{array}{l}\text { Brand image to } \\
\text { Purchase intention }\end{array}$ & 2.235 & 0.026 \\
\hline
\end{tabular}

Source: SmartPLS (2020)

The significance researcher seen from the score of $t$-values in the research that should be higher than 1.96 (Kante et al., 2018). P-value score must be smaller or equal to 0.05 so that the effect is considered significant in this research (Garson, 2016). From the table, t-value and p-value direct effect of President Election, Celebrity Endorsement, Product Variation and Brand Image towards Purchase Intention are significant, and t-value and p-value direct effect of Celebrity Endorsement to Brand Image is significant. T-value and P-values of indirect effect of Brand Image which mediates the Celebrity Endorsement with Purchase Intention is significant. 
Lidia Agustin, et al. / The Impact of President Election, Celebrity Endorsement, and Product Variation to Brand Image and Purchase Intention on Sang Pisang Business / 201 - 217

Table 3. Demographic Data of Respondents

\begin{tabular}{|c|c|c|c|c|}
\hline & & & Frequency $(n)$ & Percentage $(\%)$ \\
\hline \multirow{3}{*}{ Gender } & Male & & 82 & $41 \%$ \\
\hline & Female & & 118 & $59 \%$ \\
\hline & & Total & 200 & $100 \%$ \\
\hline \multirow{5}{*}{ Age } & $17-25$ years old & & 132 & $66 \%$ \\
\hline & 26-39 years old & & 39 & $19,5 \%$ \\
\hline & $\geq 40$ years old & & 26 & $13 \%$ \\
\hline & $<17$ years old & & 3 & $1,5 \%$ \\
\hline & & Total & 200 & $100 \%$ \\
\hline \multirow{6}{*}{ Domicile } & Bekasi & & 91 & $45,5 \%$ \\
\hline & Jakarta & & 70 & $35 \%$ \\
\hline & Bogor & & 15 & $7,5 \%$ \\
\hline & Depok & & 13 & $6,5 \%$ \\
\hline & Tangerang & & 11 & $5,5 \%$ \\
\hline & & Total & 200 & $100 \%$ \\
\hline \multirow{6}{*}{ Education } & Bachelor (S1) & & 107 & $53,5 \%$ \\
\hline & Senior high school & & 67 & $33,5 \%$ \\
\hline & Diploma & & 21 & $10,5 \%$ \\
\hline & Junior high school & & 3 & $1,5 \%$ \\
\hline & Postgraduate (S2/S3) & & 2 & $1 \%$ \\
\hline & & Total & 200 & $100 \%$ \\
\hline \multirow{5}{*}{ Occupation } & Student & & 93 & $47 \%$ \\
\hline & Employee & & 72 & $36 \%$ \\
\hline & Entrepreneur & & 30 & $15 \%$ \\
\hline & Other & & 5 & $2 \%$ \\
\hline & & Total & 200 & $100 \%$ \\
\hline
\end{tabular}

Source: Constructed in Microsoft Excel (2020)
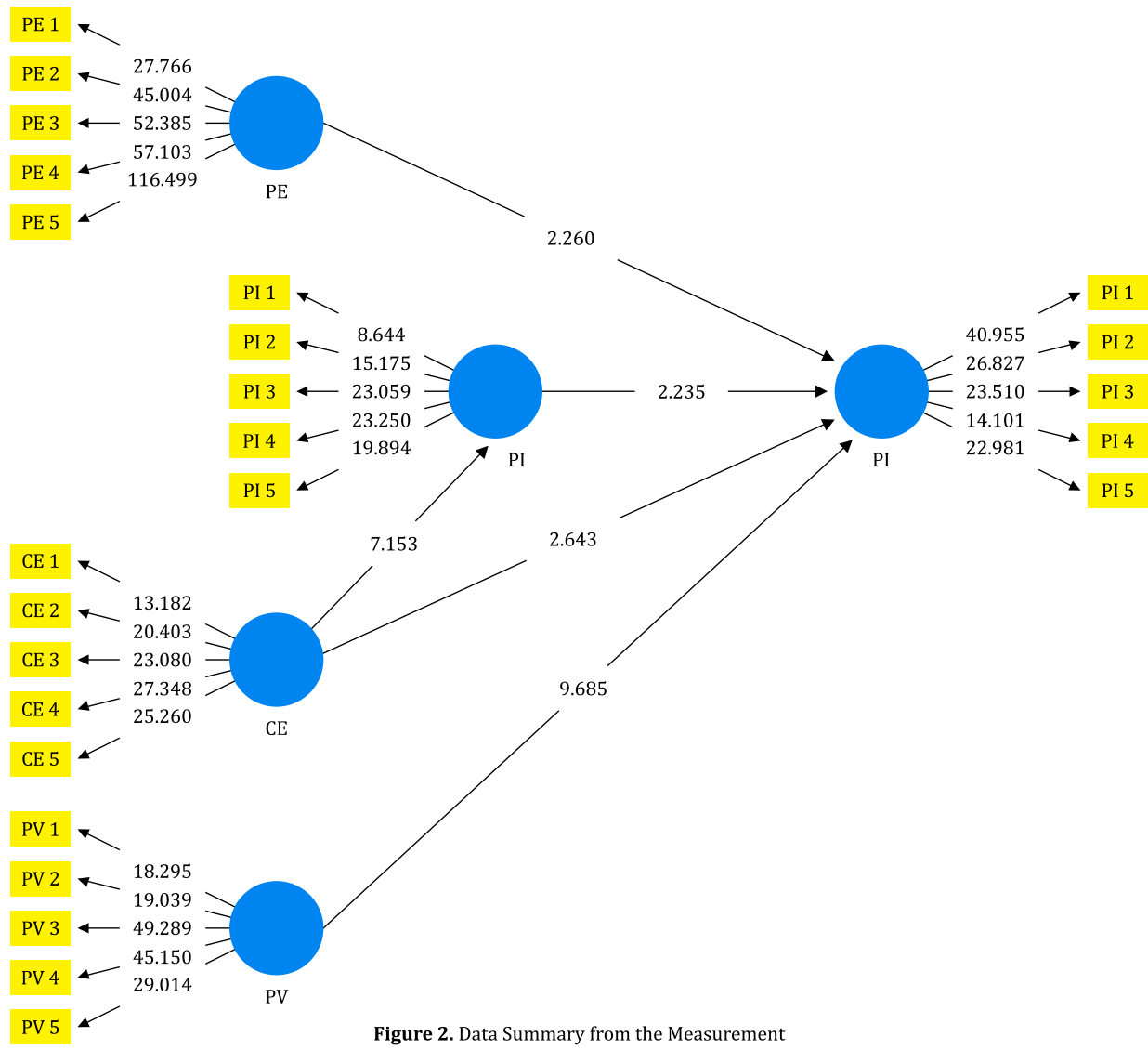

Source: SmartPLS (2020) 


\section{Interpretation of Results}

\section{President Election to Purchase Intention}

The hypothesis for the effects of President Election to Purchase Intention was determined as the followings.

H1 :Presidential election positively affect the purchase intention.

Seen from the t-value and p-value of President Election to Purchase Intention, the value of $\mathrm{t}$-value is 2.260 and $\mathrm{p}$-value is 0.024 , which means that the President Election positively affect the purchase intention. From the hypotheses in the research, the research model will accept the $\mathrm{H} 1$ as the research shows that the President Election has a direct effect towards the Purchase Intention. The effect of President Election towards Purchase Intention is also shown to be significant.

The respondents quite agree with the statement in this research questionnaire that they are interested to buy Sang Pisang because the respondents know that Sang Pisang is owned by Jokowidodo's son as the candidate of President Election in 2019. 98.5\% of total respondents are above 17 years old, and at this age people will more aware with election, because they should join to vote. the Presidential Election make them have purchase intention of Sang Pisang products, this is because president election is the most powerful political event in democratic country like Indonesia, they give their attention and it causes the respondents want to know more about the life of the presidential candidate, including the business owned by the family of the presidential candidate. According to (Maulana \& Prasetia, 2019), President Election 2019 has a big difference when compared to the previous election, the difference is in the legislative and presidential elections held in the same time in Indonesia, because of this, the 2019 Election is considered as the biggest democratic event in Indonesia's history, it causes citizen become more enthusiastic to recognize each candidate Elections that will lead Indonesia.

The hypothesis testing result is in line with the theory of (Lobo et al., 2016) that Government, especially presidential elections, can affect the results obtained by a community because of the influence of a figure who is an important person or famous either directly or indirect, so presidential elections have a positive relationship with Purchase Intention in Sang Pisang Business because in Indonesia, Presidential Election is the most powerful political event because the President has an important position for a country while Sang Pisang is owned by Kaesang Pangarep as the son of Mr. Jokowidodo which is the one of President Election candidates.

\section{Celebrity Endorsement to Purchase Intention}

The hypothesis for the effects of Celebrity Endorsement to Purchase Intention was determined as the followings.

H2 :Celebrity Endorsement positively affect the purchase intention.

Seen from the t-value and p-value of Celebrity Endorsement to Purchase Intention, the value of t-value is 2.643 and p-value is 0.008 , which means that the Celebrity Endorsement positively affect the purchase intention. From the two hypotheses in the research, the research model will accept the $\mathrm{H} 2$ as the research shows that the Celebrity Endorsement has a direct effect towards the Purchase Intention. The effect of Celebrity Endorsement towards Purchase Intention is also shown to be significant.

The respondents both women and men, agree with the statement in this research questionnaire that the respondents are interested to buy Sang Pisang because Kaesang Pangarep influenced them to buy Sang Pisang products, according to (Gong \& Li, 2017), celebrity is very influential in supporting product sales, influencing advertising effectiveness, and purchase intentions. Through celebrities, consumers can easily get advertising information and easily have an interest in advertising because of the celebrity's involvement which can lead to consumer purchase intentions (Hassana \& Jamil, 2014). Usually Kaesang use his YouTube and Instagram to do the endorsement for Sang Pisang, according to (Global Web Index, 
2019), YouTube ranked number 1 as the most active social media platforms, and Instagram is number 4 , so the respondents also have interest to buy Sang Pisang products because they can easily get the information about the product by the endorsement of Kaesang Pangarep.

The significant relationship between Celebrity Endorsement and Purchase Intention also found in researches that study about Celebrity Endorsement (e,g., Aziz et al., 2019). Kaesang Pangarep as the endorsers of Sang Pisang can influence consumer purchase intentions because Kaesang Pangarep have the ability to direct consumers to buy Sang Pisang products.

\section{Celebrity Endorsement to Brand Image}

The hypothesis for the effects of Celebrity Endorsement to Brand Image was determined as the followings.

H3 :Celebrity Endorsement positively affect the Brand Image.

Seen from the t-value and p-value of Celebrity Endorsement to Brand Image, the value of $t$-value is 7.153 and p-value is 0.000 , which means that the Celebrity Endorsement positively affect the Brand Image. From the two hypotheses in the research, the research model will accept the $\mathrm{H} 3$ as the researcch shows that the Celebrity Endorsement has a direct effect towards the Brand Image. The effect of Celebrity Endorsement towards Brand Image is also shown to be significant.

This research respondents both female and male, from the different educational background, from every city in Jabodetabek area most of them agree with the statement in this research questionnaire which is the respondents believe the products that promoted by Kaesang Pangarep as the celebrity have good quality, because according to (Clark \& Horstman, 2003), celebrities have the expertise that makes products more desirable or enhances perceptions of quality. The respondent also agree that Kaesang Pangarep has a match character to promote the product of Sang Pisang.
The significant relationship between Celebrity Endorsement and Brand Image also found in researches that study about Celebrity Endorsement (e,g., Philips \& Alexanda, 2019). Kaesang Pangarep as the endorsers of Sang Pisang have the expertise to makes Sang Pisang products more desirable and enhances perceptions of quality of Sang Pisang.

\section{Product Variation to Purchase Intention}

The hypothesis for the effects of Product Variation to Purchase Intention was determined as the followings.

H4 :Product Variation positively affect the purchase intention.

Seen from the t-value and p-value of Product Variation to Purchase Intention, the value of $t$ value is 9.685 and $p$-value is 0.000 , which means that the Product Variation positively affect the purchase intention. From the two hypotheses in the research, the research model will accept the $\mathrm{H} 4$ as the research shows that the Product Variation has a direct effect towards the Purchase Intention. The effect of Product Variation towards Purchase Intention is also shown to be significant.

This research respondents most of them are young people that always want to try something new and always want to explore many things, many of them both female and male that live in Jabodetabek area agree that Sang Pisang products have many variation, so it makes them not get bored because they can explore variations of these products. According to (Sethi et al., 2017) product variations allow consumers to make various selections that can bring change and bring new things to keep consumers away from boredom, so consumers can explore the variations of these products. The product variation of Sang Pisang makes them easier to choose the product that they like, so they will feel satisfied with Sang Pisang product variations and have purchase intention to Sang Pisang products.

The significant relationship between Product Variation and Purchase Intention also found in 
researches that study about Purchase Intention (e,g., Sethi et al., 2017). The variations in Sang Pisang products can meet the various needs and tastes of different customers and the product variation will meet the specific needs and tastes of customers. Variations in Sang Pisang products can affect profitability and purchasing intention. Sang Pisang variations allow consumers to make various selections that can bring new things to keep consumers away from boredom, so consumers can explore the variations of Sang Pisang products.

\section{Brand Image to Purchase Intention}

The hypothesis for the effects of Brand Image to Purchase Intention was determined as the followings:

H5 :Brand Image positively affect the purchase intention.

Seen from the $t$-value and $p$-value of Brand Image to Purchase Intention, the value of $t$-value is 2.235 and p-value is 0.026 , which means that the Brand Image positively affect the purchase intention. From the two hypotheses in the research, the research model will accept the H5 as the research shows that the Brand Image has a direct effect towards the Purchase Intention. The effect of Brand Image towards Purchase Intention is also shown to be significant.

For the respondents, Sang Pisang brand is well known and the name of Sang Pisang is easy to remember. The research respondents agree that they believe Sang Pisang is safe for compsumption. Products with a good brand image will be more trusted by consumers and consumers will assume that products with a good brand image are safer to buy (Made et al., 2018). The respondents agree that Sang Pisang brand has a positive impression so they have purchase intention to Sang Pisang.

The significant relationship between Brand Image and Purchase Intention also found in researches that study about Brand Image (e,g., Made et al., 2018). Brand image of Sang Pisang is influence consumers' perceptions of the products so it can influence customers to purchase the products, so there is a relationship between Brand Image and Purchase Intention.

\section{CONCLUSION AND RECOMMENDATION Conclusion}

This research aims to further examine the influence of President Election, Celebrity Endorsement, Product Variation, and Brand Image towards Purchase Intention, also to examine the brand image as the mediator of celebrity endorsement to purchase intention in Sang Pisang Business. It can be seen that in the business of Sang Pisang, the presidential election, celebrity endorsement, product variation, and brand image influence consumers to have the desire to buy Sang Pisang products. This is because the average people who fill out this questionnaire are people aged from 17-25 years who are still relatively young that always get the celebrity information, follows information of presidential elections, and gets information about foods that have unique variations.

The researcher concluded the results from this research, and the conclusion are:

1. There is direct effect of President Election towards Purchase Intention of Sang Pisang in Jabodetabek, and the effect is significant.

2. There is direct effect of the Celebrity Endorsement towards Purchase Intention of Sang Pisang in Jabodetabek, and the effect is significant.

3. There is direct effect of the Celebrity Endorsement towards Brand Image of Sang Pisang in Jabodetabek, and the effect is significant.

4. There is direct effect of Product Variation to Purchase Intention of Sang Pisang in Jabodetabek, and the effect is significant.

5. There is direct effect of Brand Image to Purchase Intention of Sang Pisang in Jabodetabek, and the effect is significant.

6. There is indirect effect of Celebrity Endorsement towards Purchase Intention mediated by Brand Image of Sang Pisang in Jabodetabek, and the effect is significant. 


\section{Recommendation}

Reflecting on the results of research that has been done, it is important for culinary entrepreneurs to pay attention to several aspects that can affect the sale of food or products to be sold. In the perspective of promotion, it is important for businesses to promote their products to choose someone who has a high popularity and liked among the public, for example, is a celebrity. Celebrities have a strong influence in encouraging potential customers to buy the products offered so that the product looks more attractive and the product is believed to have good quality. Celebrities can also build a good brand image, so that buyers are more interested and increase purchase intention. Consumers will also look for products that have tastes that match their tastes. Therefore, businesses need to have some product variations, so consumers can choose which variations they like and become unsaturated because they can find various other choices. It is also important for business people to pay attention to other conditions that can affect their business, whether it can make the product grow or things that can be a threat, for example is a political situation, a political situation can be an opportunity or can be a challenge for businesses, if the political situation can be an opportunity then use these opportunities properly to make purchase intention increases, if the political situation can be a challenge then the businessman must prepare strategies to maintain his business. Practically, there are many celebrity endorsers currently to be used by entrepreneurs, especially in social media like Instagram, TikTok or Facebook. This study proves that celebrity endorser should be considered as significant factors to business survival and success.

\section{REFERENCES}

Abumalloh, R. A. (2018). A Literature Review On Purchase Intention Factors In E-Commerce. May 2018, 386-398. https://doi.org/10.15405/epsbs.2018.05.31

Adesina, A. (2016). Election Reforms: Overview and Issues, Costa Rica, Helen Kallog Congressional Review Service.

Agu, S. U., Okeke, V. O. and Idike, A. (2013). Voters Apathy and Revival of Genuine Political Participation in Nigeria. Mediterranean Joournal of Social Sciences, 04.

Alnazer, M. (2013). The moderating role of promotional benefit level and brand awareness on the effectiveness of price discount and premium. International Journal of Business and Management Invention, 2(9), 112-120. http://www.ijbmi.org/papers/Vol(2)9/Version-1/0029101120120.pdf

Aziz, Z. D. A., Omar, M. K., \& Ariffin, S. (2019). The Effects of Celebrity Endorsement towards Purchase Intention among Students in One Public University in Malaysia. International Journal of Academic Research in Business and Social Sciences, 9(5), 498-507. https://doi.org/10.6007/ijarbss/v9i5/5891

Black, I., \& Veloutsou, C. (2017). Working consumers: Co-creation of brand identity, consumer identity and brand community identity. Journal of Business Research, 70, 416-429. https://doi.org/ 10.1016/j.jbusres.2016.07.012

Chauvet, L., \& Collier, P. (2008). Aid and Reform in Failing States. Asian-Pacific Economic Literature, 22(1), 15-24. https://doi.org/10.1111/j.1467-8411.2008.00209.x

Chien-hsiung, L. (2011). A study on the relationship between the brand image and customer satisfaction in the catering businesses. African Journal of Business Management, 5(18), 7732-7739. 
Chung, S., \& Cho, H. (2017). Fostering parasocial relationships with celebrities on social media: Implications for celebrity endorsement. Psychology and Marketing, 34(4), 481-495. https://doi.org/10.1002/mar.21001

Clark, R. C., \& Horstman, I. J. (2003). Celebrity Endorsements.

Cliffs, E. (1984). Henry Mintzberg: Power In and Around Organizations 1983, Englewood Cliffs, N.J.: Prentice-Hall. 700 pages. Organization Studies, 5(4), 377-378. https://doi.org/10.1177/017084068400500419

Davcik, N. S., da Silva, R. V., \& Hair, J. F. (2015). Towards a unified theory of brand equity: Conceptualizations, taxonomy and avenues for future research. Journal of Product and Brand Management, 24(1), 3-17. https://doi.org/10.1108/JPBM-06-2014-0639

Davis, G. E., Baumgartner, M. F., Bonnell, J. M., Bell, J., Berchok, C., Bort Thornton, J., Brault, S., Buchanan, G., Charif, R. A., Cholewiak, D., Clark, C. W., Corkeron, P., Delarue, J., Dudzinski, K., Hatch, L., Hildebrand, J., Hodge, L., Klinck, H., Kraus, S., ... Van Parijs, S. M. (2017). Long-term passive acoustic recordings track the changing distribution of North Atlantic right whales (Eubalaena glacialis) from 2004 to 2014. Scientific Reports, 7(1), 1-12. https://doi.org/10.1038/s41598-017-13359-3

Diallo, M. F. (2012). Effects of store image and store brand price-image on store brand purchase intention: Application to an emerging market. Journal of Retailing and Consumer Services, 19(3), 360-367. https://doi.org/10.1016/j.jretconser.2012.03.010

Dunuwille, V. M., \& Pathmini, M. G. S. (2016). Brand image and customer satisfaction in mobile phone market: study based on customers in Kandy district. Journal of Business Studies, 3(1), 1. https:// doi.org/10.4038/jbs.v3i1.27

Etikan, I. (2016). Comparison of Convenience Sampling and Purposive Sampling. American Journal of Theoretical and Applied Statistics, 5(1), 1. https://doi.org/10.11648/j.ajtas.20160501.11

Foster, B. (2017). Impact of Brand Image on Purchasing Decision on Mineral Water Product "Amidis" (Case Study on Bintang Trading Company). American Research Journal of Humanities and Social Sciences, 2(1), 1-11. https://doi.org/10.21694/2378-7031.16023

Garson, G. D. (2016). Partial Least Squares: Regression \& Structural Equation Models. In G. David Garson and Statistical Associates Publishing.

Ghalandari, K., \& Norouzi, A. (2012). The effect of country of origin on purchase intention: The role of product knowledge. Research Journal of Applied Sciences, Engineering and Technology, 4(9), 1166-1171.

Ghozali, I. (2011). Analisis Multivariat Dengan Menggunakan SPSS (Tiga). Badan Penerbit Universitas Diponegoro.

Global Web Index. (2019). Global Web Index. https://www.globalwebindex.com/data

Gong, W., \& Li, X. (2017). Engaging fans on microblog: the synthetic influence of parasocial interaction and source characteristics on celebrity endorsement. Psychology and Marketing, 34(7), 720-732. https://doi.org/10.1002/mar.21018

Haque, A., Anwar, N., Yasmin, F., Sarwar, A., Ibrahim, Z., \& Momen, A. (2015). Purchase intention of foreign products: A study on Bangladeshi consumer perspective. SAGE Open, 5(2), 1-12. https://doi.org/ $10.1177 / 2158244015592680$

Hassana, S. R., \& Jamil, R. A. (2014). Influence of Celebrity Endorsement on Consumer Purchase Intention for Existing Products: A Comparative Study. Journal of Management Info, 4, 1-23.

Hung, L. (2011). The Presidential Election and the Stock Market in Taiwan. Jbprpapers.Com, 6(2), 36-48. http://www.jbprpapers.com/uploads/2011/september/3.pdf

Iswara, I. G. A. D., \& Jatra, I. M. (2017). PERAN BRAND IMAGE DALAM MEMEDIASI PENGARUH ELECTRONIC WORD OF MOUTH TERHADAP PURCHASE (Studi Kasus Pada Produk Smartphone Samsung di Kota Denpasar ) Fakultas Ekonomi dan Bisnis Universitas Udayana ( Unud ), Bali , Indonesia Perkembangan tekonologi yang s. 6(8), 3991-4018. 
Lidia Agustin, et al. / The Impact of President Election, Celebrity Endorsement, and Product Variation to Brand Image and Purchase Intention on Sang Pisang Business / 201 - 217

Kalieva, O. M. (2015). Development of territory brand image: The marketing aspect. Review of European Studies, 7(2), 23-28. https://doi.org/10.5539/res.v7n2p23

Kante, M., Chepken, C., \& Oboko, R. (2018). Partial Least Square Structural Equation Modelling use in Information Systems: An Updated Guideline of Practices in Exploratory Settings. Kabarak Journal of Research \& Innovation, 6(1), 49-67.

Kanter, R. M. (1979). Power Failure in Management Circuits. Harvard Business Review, 57, 65-75. https://hbr.org/1979/07/power-failure-in-management-circuits

Keller, K. L. (2001). Building Consumer-based Brand Equity: A Blueprint for Creating Strong Brands. Marketing Management, 14-19.

Keller, K. L. (2016). Reflections on customer-based brand equity: perspectives, progress, and priorities. AMS Review, 6(1-2), 1-16. https://doi.org/10.1007/s13162-016-0078-z

Kessuvan, A., Parthanadee, P., \& Buddhakulsomsiri, J. (2015). The study of consumption behaviors and factors affecting decision to purchase fishery products of consumers in the North and Northeast of Thailand. International Food Research Journal, 22(6), 2670-2678.

Kim, S., \& Thorndike Pysarchik, D. (2000). Predicting purchase intentions for uni-national and bi-national products. International Journal of Retail \& Distribution Management, 28(6), 280-291. https:// doi.org/10.1108/09590550010328544

Koshy, L., \& Manohar, S. J. (2017). Influence of Celebrity Endorsement on Brand Image of Grooming Products. SSRN Electronic Journal, October 2018. https://doi.org/10.2139/ssrn.2969781

Kumar, S., \& Venkata Ramana, V. (2019). Celebrity Endorsement, Consumer Based Brand Equity: A Literature Review. International Journal of Management Studies, VI(3), 54.

https://doi.org/10.18843/ijms/v6i3/08

Landahl, J., \& Johannesson, H. (2018). Product variety and variety in production. Proceedings of International Design Conference, DESIGN, 2, 817-828. https://doi.org/10.21278/idc.2018.0208

Lee, J. L., James, J. D., \& Kim, Y. K. (2014). A Reconceptualization of Brand Image. International Journal of Business Administration, 5(4), 1-11. https://doi.org/10.5430/ijba.v5n4p1

Lesmana, R. P., van Eymeren, M. M., \& Tanuwidjaja, F. F. (2021). The Art of Luxury: Sealy Brand Personality Identification. International Journal of Business Studies, 5(2), 101-117.

Li, R. (2018). The Secret of Internet Celebrities : A Qualitative Study of Online Opinion Leaders on Weibo. 51st Hawaii International Conference on System Sciences (HICSS-51).

Lobo, M. C., Lobo, M. C., \& Lago-peñas, S. (2016). Coattail Effects and Electoral Coordination May 2016 COATTAIL EFFECTS AND ELECTORAL COORDINATION. June. https://doi.org/10.13140/ RG.2.1.4871.3842

Made, A. A., Prabandari, P., Putu, I., Sukaatmadja, G., Nyoman, N., \& Yasa, K. (2018). the Role of Brand Image in Mediating the Influence of Positive Word of Mouth on Consumer'S Purchase Intention. International Journal of Economics, Commerce and Management United Kingdom, VI(2), 86-103. http://ijecm.co.uk/

Malik, M. E., Naeem, B., \& Munawar, M. (2012). Brand Image: Past, Present and Future Muhammad. Journal of Basic and Applied Scientific Research, 2(12), 13069-13075.

Maulana, I., \& Prasetia, A. R. (2019). PENGARUH PERSONAL BRANDING UNTUK MENINGKATKAN PARTISIPASI GENERASI MILENIAL PADA PELAKSANAAN PEMILU 2019 PENGARUH PERSONAL BRANDING UNTUK MENINGKATKAN PARTISIPASI GENERASI MILENIAL PADA PELAKSANAAN PEMILU 2019 sebelumnya , yaitu pemilu legislatif dan bers. March.

Mehrjoo, M., \& Pasek, Z. J. (2014). Impact of product variety on supply chain in fast fashion apparel industry. Procedia CIRP, 17, 296-301. https://doi.org/10.1016/j.procir.2014.01.082

Mendrofa, Y. B. (2012). Effect of Product Knowledge and Brand Image To Purchase Intention With Hp Laptop Brand Price Discounts As Variables Moderated in Surabaya. Jurnal Ilmiah Mahasiswa Manajemen, 1(4). http://jurnal.wima.ac.id/index.php/JUMMA/article/view/355 
Mohammadzadeh, R. (2015). The Effect of Brand Image and Purchase Intention on Cosmetic Products: Evidence from North Cyprus. September, 57. https://pdfs.semanticscholar.org/e982/cd35f9042d8bf018096bb480a5d1c137df3a.pdf

O., C. P., \& Alexanda Ogbonna Udu Kalu. (2019). Impact of Celebrity Endorsement on Brand Image: A Survey of GSM Users in Umuahia Urban, Abia State. Archives of Business Research, 7(3.2), 74-82. https:// doi.org/10.14738/abr.73.2.6365

Parasher, S., \& Ghosal, N. (2005). Response towards Celebrity endorsed advettising using social appeals. Management and Science, Vol. 9(1), 74-86.

Park, H. J., \& Lin, L. M. (2020). The effects of match-ups on the consumer attitudes toward internet celebrities and their live streaming contents in the context of product endorsement. Journal of Retailing and Consumer Services, 52(May 2019), 101934. https://doi.org/10.1016/j.jretconser.2019.101934

Park, T., Velicheti, K. K., Kim, Y., \& Kim, M. (2005). The Impact of Product variety on Business Operations in the Supply Chain: A Literature Review. In The Supply Chain. California Journal of Operations Management, 3. http://gebrc.nccu.edu.tw/proceedings/APDSI/2004/pdf/125.pdf

Rajagopalan, S., \& Swaminathan, J. M. (2001). A coordinated production planning model with capacity expansion and inventory management. Management Science, 47(11), 1562-1580. https://doi.org/10.1287/mnsc.47.11.1562.10254

Randall L. Calvert and John A. Ferejohn. (1983). Coattail Voting in Recent Presidential Elections. The American Political Science Review, 77, No. 2, 407-419.

Samad, I. H. B. A., Iskandar, W. F. N. W., Ismail, M., Jogeran, J., \& Kadir, M. S. A. (2019). Determinants of Employees Purchase Intention towards Celebrity Endorsement in Health and Beauty Product: A Case Study of XYZ Company. International Journal of Academic Research in Business and Social Sciences, 9(9), 1036-1053. https://doi.org/10.6007/IJARBSS/v9-i9/6417

Sekaran, U., \& Bougie, R. (2016). Research Methods For Business: A Skill Building Approach (7th ed.). John Wiley \& Sons, Ltd.

Sethi, R. S., Kaur, J., \& Wadera, D. (2017). PURCHASE INTENTION SURVEY OF MILLENNIALS. 21(2), 1-16.

Shugart, M. S. (1995). The Electoral Cycle and Institutional Sources of Divided Presidential Government. American Political Science Review, 89(2), 327-343. https://doi.org/10.2307/2082428

Somoye, K. G. (2016). The Effects of Power and Politics in Modern Organizations and its Impact on Workersâ? ${ }^{\mathrm{TM}}$ Productivity. International Journal of Academic Research in Business and Social Sciences, 6(11), 566-574. https://doi.org/10.6007/ijarbss/v6-i11/2442

Sugiyono. (2013). Metode Penelitian Pendekatan Kuantitatif Kualitatif. Alfabeta Bandung.

Sugiyono. (2017). Metode Penelitian Kuantitatif, Kualitatif, dan R\&D. Alfabeta.

Taiwo Adisa. (2010). Abuja Bomb Blasts: Odds Against IBB.

Thompson, N. A. (2013). Reliability and effectiveness Language teaching and research. Volume 3 (, 30-32.

Vahdati, H., \& Nejad, S. H. M. (2016). Brand personality toward customer purchase intention: The intermediate role of electronic word-of-mouth and brand equity. Asian Academy of Management Journal, 21(2), 1-26. https://doi.org/10.21315/aamj2016.21.2.1

Wang, Y., \& Tsai, C. (2014). The Relationship Between Brand Image and Purchase Intention: Evidence From Award Winning Mutual Funds. International Journal of Business \& Finance Research, 8(2), 27-40. http://search.ebscohost.com/login.aspx?direct=true \&db=bth\&AN=90154805\&site=ehost-live

West, K. J., \& Spoon, J. J. (2017). Coordination and presidential coattails: Do parties' presidential entry strategies affect legislative vote share? Party Politics, 23(5), 578-588. https://doi.org/10.1177/1354068815610969

Widyastutir, S., \& Said, M. (2017). Consumer consideration in purchase decision of SPECS sports shoes product through brand image, product design and price perception. International Journal of Supply Chain Management, 6(4), 199-207. 
Yoo, B., Donthu, N., \& Lee, S. (2000). An examination of selected marketing mix elements and brand equity. Journal of the Academy of Marketing Science, 28(2), 195-211. https://doi.org/10.1177/0092070300282002

Younus, S., Rasheed, F., \& Zia, A. (2015). Identifying the Factors Affecting Customer Purchase Intention. Global Journal of Management and Business Research, 15(2 Version 1.0).

Zafer, B. (2010). Celebrity Endorsement: A Literature Review Celebrity Endorsement: A Literature Review. Journal of Marketing Management, 772858957, 37-41.

https://doi.org/10.1362/026725799784870379 